\title{
Expansão da Fronteira Agropecuária e a Dinâmica do Desmatamento Florestal na Amazônia Paraense sob a Ótica da Nova Economia Institucional ${ }^{1}$
}

\author{
Expansion of the Agricultural Frontier and the Dynamics of Forest \\ Clearing in the Amazon State of Pará from the Perspective of New \\ Institutional Economics
}

\section{La Expansión de la Frontera Agrícola y la Dinámica de la Tala de Bosques en el Estado Amazónico de Pará, desde la Perspectiva de la Nueva Economía Institucional}

\author{
André Cutrim Carvalho, Dr. \\ Professor da Faculdade de Economia da Universidade \\ Federal do Pará - FACECON/UFPA. \\ Endereço completo: Av. 25 de Setembro, no 1474, Apt. 1102, \\ Bairro: Marco, Ed. Grenoble, CEP: 66093-005, Belém-PA. \\ e-mail: andrecc83@gmail.com
}

Maurício Aguiar Serra, Dr.

Professor livre-docência do Instituto de Economia da Universidade Estadual de Campinas - IE/UNICAMP. Endereço completo: Secretaria Acadêmica - Instituto de Economia da UNICAMP, Cidade Universitária "Zeferino Vaz"

Caixa Postal 6135, CEP: 13083-857, Campinas - SP. RESUMO
David Ferreira Carvalho, Dr. Professor da Faculdade de Economia e do Mestrado em Economia do Desenvolvimento Regional da Universidade Federal do Pará - FACECON/PPGE/UFPA.

Endereço completo: Av. 25 de Setembro, no 1474, Apt. 1102, Bairro: Marco, Ed. Grenoble, CEP: 66093-005, Belém-PA. e-mail: david.fcarvalho@yahoo.com.br

José Maria Ferreira Jardim da Silveira, Dr. Professor do Instituto de Economia da Universidade Estadual de Campinas - IE/UNICAMP.

Endereço completo: Secretaria Acadêmica - Instituto de Economia da UNICAMP, Cidade Universitária "Zeferino Vaz, Caixa Postal 6135, CEP: 13083-857, Campinas - SP. E-mail: jmsilv52@gmail.com

O presente artigo procura discutir a problemática do desmatamento florestal na Amazônia paraense sob a ótica da Nova Economia Institucional. A discussão sobre fronteira, instituições e mecanismo(s) de governança é importante para estruturar um panorama histórico-institucionalista sobre este tema. Observa-se que o aparato legislativo contido na chamada Operação Amazônia deu origem a Amazônia Legal, ou seja, a fronteira é uma instituição produto da criação do Estado. A hipótese básica é que a expansão da fronteira agropecuária é o elemento central do desmatamento florestal na Amazônia paraense, além de que esse avanço engloba, também, outros fatores ligados diretamente ao avanço do progresso econômico capitalista, tais como: crescimento econômico, incremento do rebanho bovino, estrutura fundiária concentrada, especulação sobre o preço da terra, crédito rural, Instituições, dentre outros. Entretanto, a principal atividade causadora do desmatamento florestal na Amazônia paraense continua sendo a pecuária de corte em regime extensivo. Nesta pesquisa, constatou-se que os mecanismos de governança adotados nas políticas federais e estaduais de gestão ambiental criados para combater o desmatamento florestal, fundamentalmente, como os investimentos direcionados para a fiscalização, licenciamento e a rastreabilidade da cadeia bovina, contribuem de maneira eficaz para a redução do desmatamento na região

Palavras-chave: Desmatamento florestal. Nova Economia Institucional. Fronteira agropecuária.

\footnotetext{
${ }^{1}$ Artigo recebido em 21.08.2013. Revisado pelos pares em 20.05.2014 (blind review). Ajustado e Aceito para publicação em 01.07.2014. Recomendado para publicação por José Ribamar Marques de Carvalho (Editor Científico). Publicado em 15.08.2014. Organização responsável UACC/CCJS/UFCG.
} 


\begin{abstract}
This paper discusses the problem of deforestation in Pará Amazon forest from the perspective of New Institutional Economics. The discussion of border institutions and governance mechanism(s) is important to structure a historicalinstitutionalist outlook on this topic. It is observed that the legislative apparatus contained in Operation Amazon gave the Legal Amazon, ie, the border is a product of the creation of the state institution. The basic hypothesis is that the expansion of the agricultural frontier is the central element of forest clearing in the Amazon Para, and that this progress also includes other factors directly linked to the advance of capitalist economic progress, such as: economic growth, increased herd veal, concentrated land ownership, speculation about the price of land, rural credit institutions, among others. However, the main cause of forest clearing activity in Pará Amazon remains the beef cattle in extensive. In this research, it was found that governance mechanisms adopted in federal and state environmental management policies designed to combat forest clearing, primarily as investments targeted for surveillance, licensing and traceability of bovine chain, contribute effectively to the reducing deforestation in the region.
\end{abstract}

Keywords: Deforestation Forest. New Institutional Economics. Agricultural frontier.

\title{
RESUMEN
}

En este trabajo se analiza el problema de la deforestación en los bosques del Amazonas Pará desde la perspectiva de la Nueva Economía Institucional. La discusión de las instituciones fronterizas y el mecanismo(s) la gobernanza es importante estructurar una perspectiva histórico-institucionalista sobre este tema. Se observa que el aparato legislativa contenida en la Operación Amazon dio la Amazonia Legal, es decir, la frontera es un producto de la creación de la institución del Estado. La hipótesis básica es que la expansión de la frontera agrícola es el elemento central de la tala de bosques en el Amazonas Pará, y que este progreso también incluye otros factores directamente relacionados con el avance del progreso económico capitalista, tales como: el crecimiento económico, el aumento de la manada ternera, la propiedad concentrada de la tierra, la especulación sobre el precio de la tierra, las instituciones de crédito rural, entre otros. Sin embargo, la causa principal de la actividad de la tala de bosques en Pará Amazon sigue siendo el vacuno de carne en extensivo. En esta investigación, se constató que los mecanismos de gobierno adoptadas en las políticas federales y estatales de gestión ambiental diseñadas para combatir la tala de bosques, principalmente por inversiones específicas para la vigilancia, la concesión de licencias y la trazabilidad de la cadena bovina, contribuir eficazmente a la reducción de la deforestación en la región.

Palabras clave: Bosque Deforestación. Nueva Economía Institucional. Frontera Agrícola.

\section{INTRODUÇÃO'}

A questão do desmatamento florestal na Amazônia Legal e, em particular, o desmatamento florestal que vem ocorrendo na Amazônia paraense não pode ser compreendida sem uma discussão sobre essa região como uma nova fronteira essencial para o desenvolvimento do capitalismo brasileiro.

Para Carvalho (2012) o desmatamento florestal na fronteira econômica do Estado do Pará está ligado com o processo de ocupação e de expansão das atividades agropecuária, madeireira e de mineração, como também com o avanço da agricultura de subsistência itinerante.

A incorporação de áreas antes inacessíveis ou relativamente despovoadas, como no caso da Amazônia, por atividades agropecuárias resulta do avanço da fronteira econômica. No caso da fronteira econômica paraense, a expansão da atividade agropecuária contou com o apoio das instituições e organizações regionais criadas pelo governo militar, com destaque para o aparato legislativo contido na

${ }^{2}$ Os autores agradecem aos pareceristas anônimos pelas valiosas contribuições. 
chamada Operação Amazônia que deu origem a Amazônia Legal, a Superintendência de Desenvolvimento da Amazônia (SUDAM) e ao Banco da Amazônia S.A. (BASA). De acordo com Carvalho (2012, p. 73):

A abertura da fronteira amazônica ocorreu de forma tensa, entre as décadas
de 1966-1979, através dos projetos pecuários beneficiados pelos incentivos
fiscal-financeiros da SUDAM e dos projetos de colonização agrícola
conduzidos pelo Instituto Nacional de Colonização e Reforma Agrária
(INCRA), [sendo que] a pecuária foi eleita como a principal atividade
econômica responsável por ocupar as terras da fronteira do Pará. Como
consequência, a política de incentivos fiscais tornou-se a maior fonte de
financiamento do desmatamento para a formação de pastagens e
pecuária de corte em regime extensivo.

O agravamento da crise fiscal do Estado brasileiro, durante a década de 1990, acabou levando as mudanças institucionais operadas na lei dos incentivos fiscais que redundou no fim dos incentivos fiscais setoriais e no redirecionamento da política de incentivos fiscais regionais, que daí em diante passou a ser chamado de renúncia fiscal, que teve como implicação direta a extinção da SUDAM e sua política de incentivos fiscais pelo Presidente da República, na época, Fernando Henrique Cardoso. Contudo, ao contrário do esperado, o desmatamento florestal continuou aumentando substancialmente, constata Carvalho (2002).

Percebe-se, portanto, que a investigação do desmatamento florestal nos limites fronteiriços requer um tratamento sobre o papel das Instituições em uma área em que a penetração do capital ocorre num espaço de conflitos sociais como consequência da luta pela terra entre posseiros, grileiros e fazendeiros. Nestes termos, Carvalho (2002, p. 02) afirma:

Numa economia de fronteira, como no caso da Amazônia paraense, os processos econômicos determinam a forma como os interesses privados se manifestam na busca da riqueza e do lucro. Os interesses privados, às vezes, podem ir de encontro aos interesses da sociedade quando os custos sociais para esta última são demasiadamente elevados.

A problemática ambiental em torno do desmatamento florestal à formação de pastagem chegou ao ponto de chamar a atenção das instituições internacionais, em particular do Banco Mundial, pelo surgimento de externalidades do tipo negativas decorrentes da destruição da biodiversidade. Conforme Carvalho (2014, p. 06):

As externalidades estão presentes sempre que terceiros ganham sem pagar por seus benefícios marginais ou perdem sem serem compensados por suportarem o malefício adicional, logo na presença de externalidades, os cálculos privados de custos ou benefícios diferem dos custos ou benefícios da sociedade.

Para os autores Fisher e Dornbush (1983), os problemas ambientais considerados externalidades negativas são vistos como falhas de mercado que exigem correções, o que implica precificar os danos garantindo que os processos 
ocorram no âmbito do mercado. Ademais, uma externalidade surge sempre que a produção ou o consumo de um bem produzem efeitos paralelos sobre os consumidores ou produtores envolvidos, efeitos estes que não são plenamente refletidos nos preços de mercado.

Em resposta a pressão internacional, o governo federal teve que instituir leis, regulamentos e órgãos para dar conta da questão do desmatamento florestal na Amazônia Legal. Carvalho (2012, p. 159-160) descreve essa questão com detalhes:

A materialização das instituições ambientais, em obediência a Lei Maior - c Constituição de 1988 - teve início com a Lei nº 6.938, de 31/08/1981, que definiu os objetivos, os instrumentos da política ambiental e os mecanismos de governança da Política Nacional de Meio Ambiente do Brasil (PNMA), criando o Sistema Nacional de Meio Ambiente (SISNAMA), caracterizado por ser uma rede de instituições com funções definidas para a execução da Política Nacional de Meio Ambiente no Brasil. Foi também criado o Conselho Nacional de Meio Ambiente (CONAMA) - com representação de organizações governamentais e organizações não governamentais - como órgão de assessoria direta do Presidente da República do Brasil com a função de propor as diretrizes das políticas nacionais de meio ambiente e de combate ao desmatamento florestal na Amazônia, além de deliberar sobre o estabelecimento das normas e padrões de qualidade ambiental. No governo do presidente José Sarney, a lei oㅡ 6.938, de 1981, recebeu uma nova redação resultando na Lei $\mathrm{n}^{\mathrm{o}}$ 7.804, de 18/07/1989. Em 22 de fevereiro de 1989, foi promulgada a Lei $\mathrm{n}^{\mathrm{o}}$ 7.735, que criou o Instituto Brasileiro do Meio Ambiente e dos Recursos Naturais Renováveis. O Instituto Brasileiro de Meio Ambiente e dos Recursos Naturais Renováveis (IBAMA) resultou da fusão de três órgãos criados no período do regime militar: o Instituto Brasileiro de Desenvolvimento Florestal (IBDF), a Superintendência de Desenvolvimento da Pesca (SUDEPE) e a Superintendência do Desenvolvimento da Borracha (SUDHEVEA).

“O Pará possui uma área de 1.247.689, $515 \mathrm{~km}^{2}$, ou seja, o equivalente a $14,6 \%$ do território brasileiro, e uma população de 7.321.493 habitantes", assevera Carvalho (2012, p. 03). Esses dados revelam a importância dessa imensa fronteira agropecuária, que deve ser entendida como sendo um novo território econômico, palco de conflitos sociais que forçam o Estado à criação de instituições com vistas ao estabelecimento das "regras do jogo" necessárias à funcionalidade das instituições privadas. Segundo Carvalho (2002, p. 03):

A fronteira é o lócus do descumprimento das leis no âmbito de uma sociedade democrática, isto é, é o lugar onde o aparato normativo e coercitivo do Estado encontra-se ausente e quando existe estar a serviço do poder da oligarquia agrária.

Neste contexto, o presente artigo foi estruturado, além desta introdução e das considerações finais, da seguinte forma: na segunda seção são discutidos os significados de fronteira numa perspectiva histórico-teórica; na terceira seção são apresentados os fundamentos teóricos sobre as instituições, a partir do enfoque da escola institucionalista; na quarta seção, são debatidos os mecanismos de governança 
utilizados para controlar e combater o desmatamento florestal na fronteira da Amazônia paraense e, por fim, têm-se as considerações finais sobre a problemática do desmatamento sob a ótica da nova economia institucional (NEI).

\section{O DEBATE SOBRE FRONTEIRA NUMA VISÃO HISTÓRICO-TEÓRICA}

Na América Latina, como já assinalou Foweraker (1982), a última grande fronteira é a Amazônia (Brasileira). As áreas de fronteiras no Brasil têm traços e processos de ocupação que as caracterizam e as diferenciam das outras áreas fora do território nacional. Segundo Velho (1976, p. 100-106):

$\mathrm{Na}$ fronteira, embora na prática a terra não esteja inteiramente disponível para o acesso a todos os imigrantes, a ideologia da "fronteira aberta" representa, no imaginário coletivo dos grupos sociais, daqueles indivíduos despossuídos de meios de produção, uma oportunidade para melhorar as suas condições de vida. De qualquer modo, talvez por isso, a fronteira seja o "lócus" por excelência da terra aparentemente ilimitada.

É de extrema importância situar a discussão sobre a teoria da fronteira e das instituições sociais como marco de referência para uma melhor compreensão do fenômeno do desmatamento florestal na Amazônia paraense, decorrente do avanço da frente agropecuária capitalista. Carvalho (2012, p. 08) assevera:

É a combinação das ações políticas e econômicas, operadas pelas instituições, que permite a formulação de políticas públicas direcionadas para solucionar os problemas sociais, econômicos e ambientais da agenda governamental. Essa interpenetração dos interesses políticos e econômicos é a chave para a compreensão das motivações dos atores no seio das instituições governamentais quanto à questão do desmatamento florestal numa zona de fronteira em processo de avanço do capitalismo.

A identificação das causas do desmatamento florestal na Amazônia paraense perpassa necessariamente pelo entendimento do significado de fronteira, enquanto um processo de expansão de uma sociedade num território ainda não suficientemente ocupado do ponto de vista econômico. Conforme Carvalho (2012, p. 09):

\footnotetext{
A fronteira pode ser compreendida como sendo uma zona de ocupação de um território relativamente vazio em termos demográficos, onde as instituições públicas responsáveis pela manutenção da ordem jurídica, com vistas ao estabelecimento das "regras do jogo" para a funcionalidade das instituições privadas, têm uma atuação precária quanto ao exercício do cumprimento das leis numa democracia.
}

Turner (1961) pode ser considerado o pioneiro e o mais importante teóricohistoriador da fronteira norte-americana, e de acordo com o autor a democracia norte-americana está fundamentada na experiência da fronteira do Oeste. Para o referido autor, o efeito mais importante da fronteira tem sido na promoção da 
democracia nos EUA, desta forma, o individualismo da fronteira tem promovido desde o início a democracia norte-americana, que chama a atenção para a importância das "terras livres" no EUA, já que a existência de uma área de terra livre e o avanço do povoamento americano rumo ao oeste explica o seu desenvolvimento.

No caso da Amazônia, o avanço da fronteira agropecuária vem se dando dentro da lógica da acumulação capitalista, porém, não se pode prescindir dos elementos institucionais que estão presentes em função dos interesses e conflitos que permeiam o processo de ocupação econômica numa região de fronteira. Turner (1961, p. 28-36) afirma:

O papel da fronteira na formação das instituições e do sentimento nacionalista dos EUA é apresentado de forma diferente da percepção dominante dos historiadores tradicionais do leste (sul e norte) que deixaram em segundo plano o processo de ocupação e pesquisa sobre a fronteira do oeste.

Ainda em seu ensaio, Turner (1961) não nega a importância que teve a luta contra a escravidão que acabou provocando a guerra da secessão entre o norte industrial e o sul agrário. Hofstader e Lipset (1968) observam que Turner tinha consciência da importância do avanço da fronteira não só do ponto de vista da conquista de territórios vazios, através da ocupação humana e econômica à formação da nação-continente norte-americana, mas também pelo papel que teve na formação das instituições dos EUA. Para Turner (1961), as grandes extensões de terras livres para ocupação, provavelmente, tenham sido a principal força motivadora dos primeiros pioneiros (farmers) para adentrar na fronteira norte-americana.

$\mathrm{O}$ avanço das frentes econômicas de expansão nas regiões de fronteira permitiu a formação de instituições adequadas ao processo do desenvolvimento social, político e econômico da nação norte-americana. Outro aspecto importante das sociedades das fronteiras norte-americanas diz respeito ao significado do sentimento nacionalista de grande nação que serviu como um antídoto contra o separatismo.

\subsection{O significado de fronteira}

Um dos autores mais importante sobre a discussão de Fronteira é Turner (1961). Este autor é considerado o pioneiro e o mais importante teórico e historiador da fronteira norte-americana. Embora o objeto da investigação de Turner tenha sido a fronteira norte-americana, ele também se referia a fronteira como uma fase do processo geral de evolução, cujo significado na formação de outras sociedades deveria ser investigado. De fato, "há várias passagens em seu ensaio, The Significance of the Sections in American History, em que Turner (1961) sugere a necessidade de investigação da fronteira na Rússia, Alemanha, Canadá, Austrália, África e Brasil”, ressalta Carvalho (2012, p. 10). Para Turner (1961, p. 38): 
A fronteira econômica deve ser vista como o limite exterior do território já ocupado por instituições sociais, econômicas e politicas; um espaço geográfico vazio em termos de densidade demográfica, o qual se encontra em processo de ocupação e que é ponto de encontro entre a barbárie e a civilização.

Na visão de Turner (1961), a fronteira não é um espaço fechado e apresenta uma determinada dinâmica caracterizada pelo que ele chamou de avanço da fronteira. Os sucessivos avanços da fronteira nos EUA ocorreram durante várias décadas, sendo que as características de cada fronteira ocupada mudavam no tempo e no espaço, de acordo com a disponibilidade dos recursos naturais e do uso produtivo dado à terra pela população migrante. Nessa perspectiva, fica evidente que a fronteira econômica exerce influência marcante na história da evolução das instituições sociais, políticas e econômicas de uma nação. De acordo com Turner (1961, p. 39-51):

A fronteira da Costa Atlântica avançou graças aos homens de negócios
ligados a indústria de pesca, a mineração, a pecuária e a agricultura familiar;
a frente de expansão da fronteira do oeste avançou graças às famílias dos
pequenos agricultores e depois com a agroindústria e a indústria
manufatureira; e a fronteira do sul dos EUA com as grandes plantações de
algodão e depois com a indústria têxtil e a pecuária. Essas fronteiras, apesar
das distâncias, realizavam um comércio de mercadorias entra elas, o que
contribui para a redução das importações de mercadorias da Inglaterra.

Carvalho (2012, p. 13) observa que "o crescimento do sentimento nacionalista do povo americano e a evolução das suas instituições tiveram a contribuição da fronteira". A legislação constitucional que definiu a independência dos três poderes e a liberdade para a criação das instituições empresariais teve o reforço das sociedades da fronteira do oeste. Logo, o avanço da fronteira deu origem à criação de novos estados e municípios que hoje fazem parte dos EUA.

Carvalho (2012, p. 14) demonstra que "o poder de aglutinação do povo norteamericano cresceu com a criação de novos estados à medida que a fronteira avançava pelo interior do território norte-americano". Quando Turner (1961) discute as questões da venda e da alienação das terras públicas da União, as instituições públicas responsáveis são vistas como um produto da pressão das sociedades locais que pertenciam à fronteira. Nota-se, deste modo, que o debate sobre o direito a terra livre foi importante para a promoção da democracia norte-americana.

\subsection{O significado de fronteira no Brasil}


Celso Furtado (1976), quando discute os fundamentos econômicos da ocupação do Brasil, procura distinguir a colonização de povoamento do território norte-americano, feita pelos ingleses, da colonização de exploração feita pelos portugueses no território brasileiro. No Brasil, as colônias de plantations da cana-deaçúcar ou do café tiveram um papel importante como empresa agromercantil exportadora de produtos para os países europeus, sobretudo, para Portugal e Inglaterra, no encerramento da etapa colonial. Porém, outras modalidades de estruturas mercantis foram responsáveis pela extensão da fronteira brasileira para além dos limites das plantations como caso das organizações econômicas das missões religiosas na Amazônia durante o ciclo das "drogas do sertão".

O significado de fronteira como um processo sistemático de ocupação geográfica levou alguns estudiosos da fronteira brasileira, tais como: Morse (1965), Velho (1976), Hébette e Marin (2004) a substituir a noção de fronteira pela de frente pioneira, onde a noção de "pioneira" explicita a ideia daquelas famílias que chegaram primeiro. Essa noção tem uma forte conotação com a teoria geral de Turner (1961) sobre o pioneiro da fronteira do oeste norte-americano vista como uma válvula de segurança importante à formação da nacionalidade das pessoas desse país.

Carvalho (2012, p. 23) afirma que no Brasil, muito mais do que uma válvula de segurança, a fronteira é vista como uma espécie de válvula de escape às tensões sociais no agrário brasileiro impedindo o aumento de mais conflitos sangrentos na luta pela terra entre latifundiários e grileiros contra os camponeses e índios. Morse (1965, p. 30-31) observa a fronteira e a ação dos bandeirantes no Brasil de forma distinta da visão histórica de Turner:

A fronteira não é uma linha ou um limite, ou um avanço da civilização, ou
um processo unilateral ou unilinear. (...) Compreender o processo brasileiro
de ocupação significa perceber a fronteira mais como interpenetração do que
como avanço; mais como uma relação com o meio do que como uma
projeção sobre ele; mais como uma busca intermitente por um jardim das
delícias; mais do que como uma construção sistemática de um. Essas
considerações por sua vez se ligam a proposições que são fundamentais para
a sociologia de uma civilização católica

Na visão de Turner (1961), a fronteira do oeste norte-americano era uma "fronteira aberta", no sentido da sua ocupação ter se dada de forma democrática, apoiada no Homestead Act de 1862, em terras livres para os farmers, ou seja, para famílias de pequenos produtores rurais. Sandroni (1999, p. 285) a descreve com detalhes da seguinte maneira:

A Lei do Homestead foi aprovada em 1862, durante o governo Lincoln, nos Estados Unidos, estabelecendo a distribuição de terras no Oeste de forma quase gratuita, na proporção de 160 acres (cerca de 65 hectares). O homestead estabelecia, em resumo, que a propriedade da terra era de quem conseguisse demarcá-la durante um dia, legitimando dessa forma as posses que os agricultores iam obtendo ao desbravar o Oeste. A lei representou um 
poderoso estímulo para a colonização do Oeste dos Estados Unidos e atraiu um enorme fluxo migratório para aquele país. Além disso, o homestead eliminava um poderoso empecilho ao desenvolvimento da agricultura, na medida em que, pela nova lei, a propriedade da terra não pressupunha a propriedade de escravos, nem essa última, a propriedade de terras.

Lênin (1980) demonstra com base nas estatísticas disponíveis até então, que nos EUA o capital subordina e transforma direta ou indiretamente as várias formas de propriedade da terra, inclusive a dos pequenos agricultores de base familiar (farmers).

\subsection{Operação Amazônia: a federalização institucional da Amazônia}

A institucionalização da Operação Amazônia se deu em três estágios: no primeiro, em dezembro de 1965, foram estendidos à Amazônia Legal todos os incentivos fiscais e creditícios; de setembro a outubro de 1966 foram votadas as leis básicas; e, por fim, em fevereiro de 1967 foi criada, por meio do decreto-lei no 288, a Zona Franca de Manaus. De acordo com Campos (1994); MI/SUDAM (1968), a federalização institucional da região - visto como um aparato de leis, decretos-leis e de criação de órgãos federais para a atuarem na Amazônia Legal - foi anunciado no discurso proferido pelo presidente Humberto Castelo Branco, em $1^{\mathrm{o}}$ de dezembro de 1966, no território do Amapá.

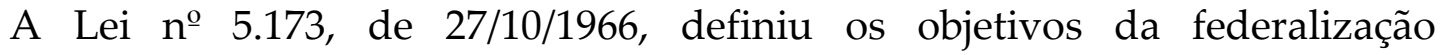
institucional que deu origem a Amazônia Legal, incorporando os estados da Amazônia Clássica e parte dos Estados do Maranhão e Mato Grosso. Para marcar definitivamente a presença da ação federal na Amazônia Legal foi criada - pela lei $n^{\circ}$ 5173 - a SUDAM. O governo federal resolveu também transformar, através da lei no 5122, de 29/09/1966, o Banco de Crédito da Amazônia em Banco da Amazônia S/A, também conhecido como BASA. Para viabilizar a política de ocupação e desenvolvimento da Amazônia Legal, o governo militar institui - através da lei no 5174, de 27/10/1966 - a política de incentivos fiscais que iria se constituir no principal instrumento sancionador dos recursos de suporte aos investidores na Amazônia.

Na concepção defendida por Carvalho (2005, p. 20-21):

A intenção da "Operação Amazônia" foi nitidamente a militarização do planejamento do desenvolvimento regional na região, produto da geopolítica da segurança nacional engendrada pelo General, Golbery do Couto e Silva.

Não é à toa que a estratégia militar de intervenção na Amazônia era fundada no binômio: segurança e desenvolvimento. Com o intuito de viabilizar as ações da União, por cima dos interesses dos estados subnacionais, o governo federal instituiu uma federação de regiões: Nordeste, Amazônia Legal, Centro-Oeste e Sul, com suas respectivas agências regionais de desenvolvimento, tais como a Superintendência de 
Desenvolvimento do Nordeste (SUDENE), Superintendência de Desenvolvimento da Amazônia (SUDAM), Superintendência de Desenvolvimento do Centro-Oeste (SUDECO) e, por fim, a Superintendência de Desenvolvimento do Sul (SUDESUL).

Desta forma, a invenção institucional da Amazônia Legal permite que a União, como agente principal, planejasse e executasse sua política de ocupação e desenvolvimento passando por cima dos interesses dos atores da região. Para submeter os governos estaduais e locais aos interesses do governo federal foram criadas novas instituições regionais e redefinidos os papéis que o governo federal e o setor privado passariam a assumir em suas dimensões geoeconômicas e geopolíticas, como será visto a seguir.

A nova estrutura institucional montada pelo governo Federal para que esses organismos federais atuassem na Amazônia Clássica - que se confundia geograficamente com a região Norte - exigiu a invenção de uma nova Amazônia: a Amazônia Legal. Esta Amazônia ampliada incorporou uma parte da região Nordeste (uma parte do Maranhão) e uma parte da região Centro-Oeste (uma parte do Mato Grosso). Para Carvalho (2012), a criação da Amazônia Legal serviu aos interesses do governo militar que, dispondo de recursos orçamentários e dos incentivos fiscais, manobrava de acordo com os seus interesses à política nacional de integração da Amazônia ao centro capitalista do Brasil - a região Sudeste.

Nestas condições, Carvalho (2012, p. 78-79) afirma:

O próprio planejamento nacional do desenvolvimento regional foi institucionalizado como instrumento político-ideológico, onde o governo militar impôs aos governos estaduais e a sociedade uma nova estratégia de ocupação e desenvolvimento. As estratégias de ocupação e desenvolvimento da Amazônia foram constantemente adaptadas às mudanças da conjuntura econômica e a preservação do poder militar representativo de uma determinada aliança entre uma burguesia industrial e financeira do centro e uma oligarquia da periferia regional representante dos capitais mercantis locais.

\section{A FRONTEIRA COMO INSTITUIÇÃO}

A interpretação teórica da fronteira e da expansão da fronteira econômica no Brasil e dentro dela da colonização, como uma das suas formas institucionais, não pode dispensar uma referência à nova organização do mundo globalizado em termos geopolíticos e geoeconômicos. Quando a ocupação sistemática de terras livres numa fronteira de recursos naturais e abundância de terras, como no caso da Amazônia Legal, passa a despertar o interesse econômico de uma elite burguesa, a institucionalização que resulta na expansão da fronteira vem acompanhada por leis específicas, e concomitantemente com a criação de organismos públicos que suporte a dinâmica da ocupação da fronteira econômica em bases capitalistas. Becker (2000, p. 9) expressa o "Tratamento Institucional da Fronteira Amazônica" nos seguintes termos: 
Na contemporaneidade, o uso do território de um Estado, de modo geral, e de sua fronteira política, de modo específico, parece, em grande parte, o resultado de fluxos e pressões gerados não só de dentro como, cada vez mais, fora dele e que escapam, de certo modo, ao controle de suas instituições e regulações territoriais tradicionalmente elaboradas. Nesse contexto, a organização do espaço econômico e de seu extenso limite fronteiriço parece, em grande parte, ditada tanto a partir da esfera central ponto de referência da soberania nacional e foco da análise a seguir - como das relações vindas do exterior. Não é demais enfatizar, desse modo, que o tratamento da questão fronteiriça na Amazônia vincula-se ao processo mais amplo de desenvolvimento e ocupação da região.

Carvalho (2012, p. 35) complementa esse pensamento ao afirmar que:

A organização do espaço amazônico e de seu extenso limite fronteiriço com os países da Pan-Amazônia remete, em grande parte, a influência geopolítica do Estado brasileiro, associada com a política de soberania nacional, mas também a influência da geoeconomia interna e externa associada à influência das relações internacionais. Contudo, a expansão da fronteira econômica no Brasil, no caso da fronteira amazônica, é mais um reflexo do dinamismo da economia brasileira a partir do polo concentrador $\mathrm{e}$ centralizador do capital industrial e do capital financeiro.

Portanto, são os imperativos do processo de acumulação de capital no território nacional que acabam determinando a transição das frentes de expansão às frentes pioneiras na fronteira. "Igualmente são os imperativos da necessidade incessante de acumulação de capital que acabam determinando as formas de ocupação - dentre as quais se destacam as práticas da colonização espontânea, empresarial e governamental - na fronteira amazônica", Hébette e Marin (2004, p. 7577).

Diante deste cenário, é possível constatar que a velocidade de ocupação das terras livres na fronteira pode interessar tanto a uma elite capitalista que uma disputa por terras livres (ou não) pode conduzir a expropriação de terras de terceiros por meio de processos violentos ou fraudulentos de acumulativa primitiva e, por conseguinte, a elevação dos conflitos em torno da luta pela terra. Portanto, "se a luta pela posse da terra for vencida pela frente de expansão capitalista agropecuária, então haverá a possibilidade de ocorrência de uma fronteira fechada e, quando isso acontece, diminuem as alternativas do desenvolvimento da agricultura com base na pequena unidade de produção familiar", sustenta Carvalho (2012, p. 35).

Velho (1972) admite a existência de um terceiro tipo de fronteira, que ele chama de fronteira aberta controlada. A fronteira quando aberta, com ou sem restrição do Estado, abre a possibilidade para penetração de uma gama de atores sociais, tais como camponeses, fazendeiros e empresas. Todos veem à fronteira como o lugar da terra ilimitada disponível, mesmo sabendo que a terra é limitada em termos físicos, jurídicos e econômicos e econômicos do ponto de vista do seu aproveitamento para a agricultura. 
Nas palavras de Velho (1979, p. 100), “O lócus por excelência da terra "ilimitada" é, obviamente, a fronteira". Carvalho (2012, p. 36) afirma que:

Embora na prática, mesmo na fronteira, a terra não esteja aberta a todos sem limite, ela representa no imaginário coletivo das famílias dos "sem terra" essa imagem ideológica quando contrastada com situações sociais em que realmente vivem pequenos produtores agrícolas ou mesmo dos despossuídos de meios de produção os quais vivem em péssimas condições sociais nas cidades mais próximas da fronteira.

Para essas famílias, a fronteira é vista como uma possibilidade de uma mobilidade social ascendente e uma saída para sair da subordinação formal do trabalho ao capital, admite Velho (1972). Para Carvalho (2012), a elite capitalista das frentes pioneiras de ocupação, nas áreas de fronteiras, tem no imaginário coletivo deles uma imediata acumulação de capital e o aumento do poder de comando sobre a forma de dinheiro. Por tudo isso, a fronteira econômica é um lugar muito importante para os dois modelos de desenvolvimento - o modelo composto pelas frentes de expansão e os das frentes pioneiras capitalistas - daí o interesse do Estado em controlar o movimento fronteiriço na região, o que coloca o avanço da fronteira agrícola como uma instituição que merece ser estudado como um ponto de referência.

Diante do exposto, podemos entender a economia da frente de expansão, como sendo uma economia do excedente, cujas famílias que fazem parte dessa frente produzem, principalmente, para a própria subsistência e secundariamente à troca dos seus produtos excedentes de acordo com as suas necessidades que desejam obter no mercado. Já a frente pioneira capitalista exprime um movimento econômico cujo resultado imediato é à incorporação de novas terras das regiões de fronteira à economia de mercado em bases capitalistas. Ela é precursora do ponto de vista do capital, já que é uma frente capitalista de ocupação territorial representada pelos grandes empresários, latifundiários, instituições financeiras (bancos), casas de comércio, estradas e todo o aparato institucional do Estado que se põe para mitigar os conflitos. Para Martins (2009, p. 135-136):

A concepção de frente pioneira compreende, implicitamente, a ideia de que
na fronteira se cria o novo, uma nova sociabilidade, fundada no mercado e
na contratualidade da das relações sociais. No fundo, consequentemente, a
frente pioneira é mais do que o deslocamento da população sobre o território
no Brasil, pois acaba sendo uma situação espacial e social que convida/induz
à modernização, à formulação de novas concepções de vida, à mudança
social.

Foweraker (1982) toma o conceito de fronteira pioneira num sentido diferente daqueles associados ao caráter cíclico do crescimento econômico e da ocupação da terra no Brasil. O referido autor observa que os ciclos de crescimento têm sido acompanhados de uma repentina intensificação da demanda de diferentes produtos de exportação no mercado mundial - tais como açúcar, ouro, café e 
borracha - e têm dependido, através dos séculos, do surgimento de novas procuras na expansão daquele mercado. Para Foweraker (1982, p. 31):

A fronteira pioneira, ao contrário, tem-se expandido em resposta às demandas do mercado nacional e em função da acumulação econômica dentro da economia nacional desde 1930. A fronteira pioneira, nestes termos, é um processo histórico específico de ocupação de novas terras.

O período de ocupação de novas terras na fronteira corresponde à fase de ocorrência das mais altas taxas de industrialização e urbanização no Brasil, e começa no momento em que a economia brasileira, pela primeira vez, experimenta um grande excedente de mão-de-obra que, com parcas possibilidades de emprego nos grandes centros urbanos, dirige-se no sentido da ocupação de novas terras, ou seja, da mesma forma que a economia brasileira cresce "em profundidade", em termos estruturais, nos centros industriais e financeiros, também aumenta "em largura" pela expansão das suas fronteiras agrícolas e pecuárias.

Quando a história econômica é vista ciclicamente, os ciclos históricos - ciclo da cana-de-açúcar, da mineração, do café e da borracha - representam a ascensão e queda da atividade econômica em uma ou outra região do Brasil em diferentes épocas, mas não demonstram o que existe de comum entre eles, ou seja, que no caso dos ciclos da fronteira pioneira é importante que a economia nacional seja claramente uma economia tipicamente capitalista. Foweraker (1982, p.32) observa que:

Pela abordagem dos ciclos históricos, não parece importante que a base do impulso à exportação tenha sido o trabalho escravo, servil ou "livre"; em outras palavras, a análise não se dá a partir do modo de produção capitalista, mas simplesmente é colocada ao nível da demanda do mercado internacional.

De acordo com Carvalho (2012), o avanço da fronteira decorre dos movimentos das pessoas e atividades econômicas que acabam transformando, integrando e ampliando novas relações sociais em bases capitalistas do espaço ocupado ou em processo de ocupação territorial. É claro que o processo de avanço da fronteira pioneira deve ser visto dentro da dinâmica cíclica capitalista, mas com a diferença crucial de que o ciclo de acumulação e apropriação do excedente pode ocorrer simultaneamente em diversas fronteiras do país.

Cabe destacar que a fronteira não exprime toda e qualquer atividade econômica, cuja produção é voltada para o mercado exterior, mas sim uma atividade particular que integra as regiões inexploradas à economia nacional, sendo esse processo impulsionado pelas forças e contradições próprias de uma economia em desenvolvimento. Isso é importante porque, embora os mecanismos usuais de acumulação de capital na fronteira de uma nação possam, em determinadas situações, não serem especificamente capitalistas em termos dos métodos de subsunção formal ou subsunção real do trabalho alheio, como estudados por Marx (1982), o fato é que o capital pode se assim for necessário à acumulação do capital 
industrial, recorrer a métodos de acumulação primitiva. Na visão de Carvalho (2012, p. 38):

O capital industrial e financeiro numa formação econômico-espacial, já dominada por relações sociais de produção especificamente capitalistas, tem como intento fixar o seu domínio territorial na fronteira econômica por meio da intermediação do capital mercantil que faz uso, como lhe peculiar, das formas violentas de expropriação de terras e de exploração do trabalho alheio por métodos de acumulação primitiva.

Nesse ambiente de violência e de insegurança institucional as instituições governamentais, criadas para combater o desmatamento na região amazônica, não funcionam no sentido do cumprimento das normas estabelecidas por lei.

\subsection{A Nova Economia Institucional}

A Nova Economia Institucional (NEI), liderada por Douglass North (1990) e Williamson (1985), tem como objetivo desenvolver uma teoria econômica das instituições e prover um conjunto de evidências históricas sobre como as instituições afetam o desenvolvimento econômico dos países mundo a fora, sendo assim, uma instituição pode ser caracterizada pela capacidade de delimitar escolhas e possuir mecanismos de tomada de decisões. Para Carvalho (2012, p. 38):

As instituições reduzem certos custos de transação, isto é, os de fazer e
manter um contrato, mas ao mesmo tempo engendram outros custos, além
do que, elas diminuem o grau de incerteza proveniente de comportamentos
imprevisíveis e, consequentemente, facilitam a identificação de parceiros
adequados para as transações e a elaboração de contratos, levando em conta
o maior número possível de eventualidades.

Entretanto, as instituições podem aumentar os custos de uma transação ao elevar, por exemplo, o número de parceiros na barganha e interação, de qualquer maneira que sejam definidas, a ênfase estará nas regras que regulam comportamentos recorrentes, pondera North (1990). Tendo como base os pressupostos teóricos de North (1990), as instituições podem ser formais (leis, decretos-lei e regulamentos do Estado que balizam o comportamento dos membros de uma dada sociedade) e informais (convenções e códigos criados historicamente pela sociedade).

Para o referido autor, as instituições formais interagem com as informais e essa ação pode complementar ou melhorar a eficácia das últimas ou mesmo modificá-las ou substituí-las com o tempo, já que essas mudanças consistem de ajustamentos marginais ao complexo de regras, normas e imposições regulamentares que compõem a estrutura institucional de país.

Dessa forma, as mudanças institucionais disruptivas e descontínuas, tais como as revoluções e invasões são casos singulares que, mesmo elas, não estão isentas dos efeitos das instituições informais. Sob a ótica de Carvalho (2012, p. 68): 
Outra questão importante relacionada ao movimento teórico do novo institucionalismo, liderado por Douglas North, engloba as seguintes características: a) reconhece que o mundo real não se aproxima da concorrência perfeita, que é introduzida no cenário uma sociologia institucional; b) nesta é construído um modelo de instituição idealizada e funcional que no limite recria as condições favoráveis à livre concorrência; c) o modelo anglo-saxão de economia de mercado é descrito como o mais próximo desse modelo e a evidência da importância dessas instituições para o desenvolvimento; d) o subdesenvolvimento decorre da existência de instituições que inibem as relações econômicas; estas instituições persistem porque obedecem a uma racionalidade política de grupos não competitivos encastelados no Estado.

Além disso, o institucionalismo de North (1990) não é propriamente um determinismo institucional, mas a suposição de que o caminho do desenvolvimento econômico é moldado por instituições embedded na economia, para usarmos uma expressão cara a Polanyi (1957). Ao contrário das abordagens anteriores - onde as instituições do capitalismo são explicadas pela referência à luta de classes, tecnologia e/ou poder de monopólio - a abordagem do custo de transação do mercado sustenta que estas instituições têm a principal finalidade e efeito de economizar custos de transação numa linguagem que combina ao mesmo tempo interpretações econômicas e jurídicas (leis dos contratos).

Portanto, o aprofundamento teórico sobre as instituições sociais e os mecanismos de governança visa completar o conhecimento necessário para a compreensão do papel mediador do governo e de suas agências para mitigar os conflitos ambientais associados à questão do desmatamento florestal.

\subsection{Origem e evolução do pensamento institucionalista: o Estado da Arte}

A escola institucionalista tem sua origem nos EUA33. Segundo Carvalho (2012, p. 40):

O pensamento institucionalista da velha escola norte-americana pode ser sintetizado por suas ideias básicas: a primeira é de que a economia deve ser analisada em sua totalidade, distinta dos fenômenos particulares que constituem a realidade econômica; a segunda, a atividade econômica não deve ser vista apenas como a soma das atividades individuais movidas pela busca do ganho econômico; e a terceira de que a sociedade econômica e suas instituições estão sujeitas a transformações no tempo.

Os institucionalistas norte-americanos também defendiam reformas democráticas que permitissem melhorar a distribuição da riqueza e da renda. Apesar das importantes contribuições dos institucionalistas norte-americanos pioneiros, tais como: Veblen, Commons, Wesley e Galbraith, a abordagem teórica pretendida neste

\footnotetext{
3 Dentre os pensadores que contribuíram para a formação da escola institucionalista destacam-se: Thorstein Veblen (1857-1929), John Rogers Commons (1862-1945) e Wesley C. Mitchel (1874-1948).
} 
artigo estará centrada nos elementos conceituais da escola neo-institucionalista. Carvalho (2012, p. 40-41) propõe a seguinte interpretação:

Por instituições, os institucionalistas entendem qualquer padrão de
comportamento coletivo, constitutivo do universo cultural de uma
sociedade. Essa noção de instituição inclui, portanto, não apenas as
organizações criadas pelos governos (agências administrativas) ou pela
iniciativa privada para fins específicos - escolas, bancos, famílias - mas o
conjunto de usos e costumes, leis e códigos de conduta - religião, modos de
pensar, hábitos e convenções sacramentadas.

As instituições econômicas, tais como o monopólio, a moeda, o crédito, as relações sociais entre empresas e trabalhadores, as leis sociais, o sistema previdenciário, a delimitação de fronteira de fronteira legal ou territorial, os padrões de distribuição da riqueza e da renda, constituem também alvo principal dos debates institucionalistas.

Os neo-institucionalistas criticam os economistas neoclássicos que defendem leis imutáveis na economia e a ideia de equilíbrio do sistema econômico. Williamson (1985), por exemplo, é um institucionalista que rejeita a velha ideia de uma ordem social harmônica e reconhece a existência dos conflitos de interesses entre grupos e desajustes inerentes à vida econômica. Nesse universo de conflitos, os economistas institucionalistas admitem a possibilidade de intervenção do Estado, para reconciliar os contendores, por meio de políticas econômicas capazes de assegurar o bom funcionamento do sistema econômico. Outro aspecto importante, defendido por Carvalho (2012, p. 41), "é a rejeição da racionalidade econômica como elemento único da tomada de decisões quando se trata de um mundo de incerteza em relação ao futuro desconhecido".

Os neo-schumpeterianos, também, incorporam as instituições em seu arcabouço evolucionista que destaca a dinâmica dos processos de mudança estrutural do sistema econômico como produto das inovações tecnológicas. Nelson (2005), por exemplo, destaca a importância das instituições financeiras e do sistema nacional de inovações para a emergência das inovações tecnológicas por intermédio dos mecanismos de busca (search), seleção (selection) e aprendizado (learning) que, via expansão das firmas inovadoras e imitadoras, sancionam e difundem as inovações de produto, de processos e de gestão empresarial que acabam provocando mudanças estruturais e institucionais perceptíveis na economia de mercado.

Carvalho (2012) observa que o economista de tradição neoclássica pensa o sistema econômico como sendo coordenado pelos mecanismos de preços, e a sociedade torna-se não uma organização, mas sim um organismo autorregulado pelo sistema de preços. Isto não quer dizer que os indivíduos não façam seus planos em termos prospectivos e não façam suas escolhas entre alternativas possíveis e viáveis com base no princípio da racionalidade.

Entretanto, por trás disso tudo, a teoria neoclássica assume a hipótese de que a alocação dos recursos é diretamente dependente do mecanismo de preços. $\mathrm{O}$ 
pensamento alternativo representado, principalmente, por Joseph Alois Schumpeter, John Maynard Keynes, Michael Kalecki, ao contrário, sem desconsiderar a relevância do sistema de preços, admite uma função de coordenação do empresário no que tange a tomada de decisão de produção e a formação dos preços.

\subsection{A importância dos mecanismos de governança}

Segundo Carvalho (2007), a governabilidade é algo próprio das democracias. Desta forma, a governabilidade deve ser entendida como a capacidade sociopolítica de um governo democrático procurar não só viabilizar acordos ou pactos políticos partidários para dar sustentação à implementação de um determinado projeto de desenvolvimento nacional, mas também enfrentar os desafios e aproveitar as oportunidades para concretizar o pacto social visando à melhoria do bem estar social.

Ademais, a governabilidade democrática deve se constituir numa estratégia inteligente de ações pró-ativa para construção de capacidades voltadas para o desenvolvimento sustentável. Carvalho (2012, p. 62) complementa essa ideia quando afirma que:

Tais capacidades dependem da inter-relação entre o sistema institucional
(governance), das capacidades dos atores políticos, econômicos e sociais
(atores dirigentes) e da quantidade e qualidade das lideranças
transformadoras disponíveis. A governança deve ser entendida como sendo
a capacidade governativa do Estado, tomada em sentido amplo, o que
envolve sua capacidade de gestão governamental na formulação e
implementação das suas políticas públicas e na consecução de metas
coletivas. Do ponto de vista institucional, o conceito de governança refere-se
ao conjunto de mecanismos e procedimentos para lidar com a dimensão
participativa e plural da sociedade, o que implica a necessidade para se
expandir e aperfeiçoar os meios de interlocução e de administração do jogo
político de interesses.

Quando Williamson (1996) investiga a questão da governança, ele classifica dois tipos de instituições de governança: a governança espontânea e a governança dirigida ou intencional. A governança espontênea, que é conduzida pelas organizações econômicas com base no princípio de que a maximização dos interesses individuais, resulta em um bem estar social por meio do sistema de preços do mercado, a chamada "mão invisível". Entretanto, devido as falhas do mercado, o governo (a mão visível) por meio das instituições governamentais pode impor controles sobre as instituições econômicas vigentes;

“Já a governança intencional é o conjunto de leis e regulamentações que normatizam a instituição ("a lei"), enquanto que a governança espontânea mostra as práticas de resoluação de problemas, neutralizando as leis e a organização para tornar a resolução de disputas rápidas e sem custo", assevera Williamson (1996). O bom desempenho da economia depende do design estrutural de todas as relações 
sociais, principalmente, entre o Estado e o setor privado, entre políticos e burocratas do governo e entre cidadãos e o Estado.

Os agentes privados e cidadãos devem beneficiar-se quando se comportam de modo a favorecer o interesse público, mas devem ser penalizados quando não o fazem. Na visão analítica de Przeworski (1998), o mesmo princípio deve ser aplicado aos burocratas e políticos, pois o Estado desempenha um papel exclusivo, uma vez que é ele que define a estrutura dos incentivos aos agentes privados, exercendo o poder de coerção legitimado pela lei que obriga a prática de algumas ações ou as proíbe, e pode alterar os preços relativos através do sistema fiscal.

Há dois mecanismos de regulação numa economia capitalista: o mecanismo de preços e o mecanismo normativo regulador dos desvios do mercado. Na visão de Carvalho (2012, p. 64), “o Estado utiliza o seu aparato normativo - leis e regulamentos e organizações públicas - para impor medidas de persuasão e de punição para salvaguardar dos direitos e obrigações dos cidadãos". Coase (1988) identifica que o próprio Estado pode direcionar medidas corretivas às empresas para que possam usar certos métodos de produção que impeçam, por exemplo, a poluição do ar com fumaça ou ainda limitar certos tipos de negócios que possam provocar danos à natureza e a sociedade por meio de regulamentos restritivos ao desmatamento ou mediante a criação de zoneamentos econômico-ecológicos indicativos do uso da terra para determinadas atividades econômicas.

Carvalho (2012), ainda, observa que as restrições impostas às atividades predatórias ou prejudiciais a natureza, e aos membros da sociedade, podem ser realizadas via mecanismo de preços ou via mecanismos institucionais de controle. É preciso ponderar sobre a ineficiência do mecanismo de preço do mercado para resolver todos os problemas econômicos sociais e ambientais da sociedade contemporânea, por conseguinte, quando há desvios de condutas, o governo pode usar os seus mecanismos normativos legais de persuasão ou de punição, por exemplo, o governo pode usar a cobrança de impostos como um mecanismo de governança para punir os infratores das leis e dos regulamentos; outro percurso institucional seria utilizar a isenção, redução e deferimento de impostos como um mecanismo de governança para premiar os cumpridores das leis e regulamentos.

\subsection{Instituições, regimes de propriedades e meio ambiente}

Primeiramente, é preciso entender o papel das Instituições como formadoras de convenções sociais definidoras do padrão de comportamento dos membros de uma sociedade No caso das instituições definidoras dos regimes de propriedade, particularmente numa fronteira econômica capitalista, estas podem ser geradoras de conflitos associados ao desenvolvimento econômico versus impactos no meio ambiente. Segundo Alston, Libecap e Mueller (1999, p. 8-10): 
implique em destruição dos recursos naturais e da biodiversidade existente na Amazônia. Fronteiras tem alto potencial para melhorar o status econômico e social dos assentados, mas a efetivação disso depende dos regimes de direitos de propriedade e quão flexíveis são estes regimes para acomodar as novas condições econômicas emergentes. Se os direitos de propriedade são claramente assinalados e regulamentados, os indivíduos podem explorar os recursos da fronteira de modo a maximizar sua riqueza com a redução dos problemas ambientais.

De acordo com Carvalho (2012, p. 65):

Fronteiras também apresentam um elevado potencial para gerar conflitos sobre direitos de propriedade, associados a ocupação produtiva ou especulativa da terra, porque as fonteiras são o lugar onde as instituições legais e as organizações governamentais estão ausentes.

A provisão de infraestrutura governamental e de serviços públicos, tais como títulos de terra e mecanismos legais é socialmente cara e somente pode ser fornecida ao longo do tempo quando os preços das terras sobem.

Outro aspecto institucional importante diz respeito ao direito de propriedade. "O direito de propriedade abrange o direito de uso, de contratar e obter renda de um recurso e de transferir para terceiros os direitos sobre um recurso", Carvalho (2014, p. 08). Coase (1960) pondera que a conjunção de direitos de propriedade definidos e a inexistência de custos de transação fazem com que uma negociação, que envolva poucos poluidores e vítimas da poluição, alcance uma solução de eficiência paretiana, tornando-se desnecessária a regulamentação.

Autores como Alston, Libecap e Mueller (2003) afirmam que os direitos de propriedade consistem de um conjunto de direito privado pleno onde qualquer indivíduo pode usar um recurso, um bem ou serviço independemente da forma desde que seu uso não afete o uso de outros. Neste sentido, como reforçam os autores, o direito privado de uso de um ativo implica que tal uso não deve interferir nos direitos de propriedade de outros; o direito de excluir outras pessoas de usar o mesmo ativo se assim quiser; o direito de extrair renda a partir do ativo que lhe pertence; o direito de transferir ou alienar por venda ou doação o ativo ou recurso para alguém de sua escolha.

Carvalho (2014) estrutura os principais tipos de direitos de propriedade da seguintemaneira, a saber: i) o direito de uso do ativo; ii) o direito da apropriação dos retornos dos ativos; e iii) o direito para mudar a forma, substância, e locação do ativo, sendo que cada um desses atributos implica exclusividade e através deles os proprietários adquirem o direito de usarem os recursos da terra, investirem e transacionarem por outros ativos ou recursos. Para Vatn (2005, p. 253-283):

Um regime de propriedade é a estrutura de direitos e deveres que caracterizam as relações entre indivíduos de uma sociedade com respeito a um ativo ou benefício proporcionado por algum recurso natural. Há vários regimes de propriedade: a propriedade privada capitalista, a propriedade 
privada camponesa de uso familiar, a propriedade comunal e a propriedade de acesso aberto.

Contudo, apesar dessa diversidade de formas de propriedade, é a propriedade privada capitalista a configuração dominante no modo de produção capitalista. Demsetz (1967) admite que o direito de propriedade é a forma pela qual os membros de uma sociedade organizada podem defender os seus direitos e interesses junto ao sistema judiciário de forma a reduzir riscos e custos da transação do seu patrimônio.

Para Vatn (2005), quanto ao regime dos recursos, as questões institucionais podem ser divididas basicamente em três tipos: $1^{1}$ ) é sobre quem consegue acesso a posse e uso dos recursos, isto é, a questão da distribuição dos recursos; 2a ) diz respeito ao custo de criar e manter as instituições ambientais para o uso individual ou coletivo de um recurso, isto é, os custos de transação envolvidos; e, por fim, 3aa) o efeito que um regime de recursos pode ter sobre como os problemas dos direitos de propriedade são percebidos, que interesses esse regime defende e quais os valores são promovidos.

Ostrom e Hess (2007) chamam a atenção para o fato de que os direitos de propriedade - garantidos por lei - definem as ações que indivíduos podem tomar em relação a outros sobre a propriedade de algum ativo ou recurso natural. Nesse contexto, Anuatti Netto (2004) classifica três tipos de recursos encontrados no meio ambiente: o primeiro refere-se ao direito de uso, no qual o proprietário do ativo (ou do recurso) decide como irá usufruir, transformar ou mesmo destruir o ativo (ou o recurso disponível); o segundo está relacionado ao direito de exploração do recurso em que o proprietário decide a forma com que irá usufruir a renda do ativo ou do recurso, seja pela exploração direta ou pela exploração indireta mediante a cessão a outros recebimento de renda por tempo determinado estabelecido em contrato; e, por fim, há ainda o direito de alienação do proprietário do ativo para terceiros de forma permanente ou temporário.

Carvalho (2012) defende a importância da regulamentação ambiental como um instrumento de política pública minimizar os impactos ambientais do desmatamento na Amazônia paraense, já que os efeitos do comércio exterior sobre os recursos naturais dependem diretamente do regime de direitos de propriedade. Contudo, os direitos de propriedades nas fronteiras amazônicas são violados por diversas razões, tais como: debilidade e burocracia dos sistemas judiciais e políticos, e insuficiência de recursos financeiros para criar ou manter as operações dos órgãos responsáveis pelo cumprimento dos direitos da propriedade. 


\section{MECANISMOS DE GOVERNANÇA ALTERNATIVOS AO COMBATE DO DESMATAMENTO FLORESTAL: O LICENCIAMENTO AMBIENTAL E CADASTRO AMBIENTAL RURAL}

Tão logo Luiz Inácio Lula da Silva assumiu Presidência da República do Brasil, em 2002, ele nomeou para a pasta do Ministério do Meio Ambiente a senadora pelo Estado do Acre, Maria Osmarina Marina Silva Vaz de Lima. Neste mesmo ano, o desmatamento da floresta amazônica tinha alcançado níveis elevados a ponto de chamar atenção da comunidade internacional. Em 2004, após meses de preparação e divesas consultas, foi lançado pelo governo federal em abril de 2004 - ano que em que a taxa de desmatamento alcançou seu maior nível $\left(27 \mathrm{mil} \mathrm{Km}^{2}\right.$ de área desmatada) - o Plano de Ação para a Prevenção e Controle do Desmatamento da Amazônia Legal (PPCDAM), contendo os seguintes eixos de trabalho: $1^{o}$ ) ordenamento fundiário e territorial; $2^{\underline{o}}$ ) monitoramento e controle ambiental; $3^{\circ}$ ) fomento a atividades produtivas; e $4^{\underline{o}}$ ) infraestrutura ambientalmente sustentável, porém este último eixo foi transferido para o Plano Amazônia Sustentável.

Em dezembro de 2004, foi editada e institucionalizada a Portaria do Ministério do Desenvolvimento Agrário (MDA), e do Instituto Nacional de Colonização Agrária (INCRA), de número dez, que obrigava o recadastramento dos imóveis rurais nos municípios da Amazônia Legal. As primeiras medidas diretas de combate ao desmatamento florestal na região tiveram início em 2005. As ações de fiscalização promovidas pelo Instituto Brasileiro do Meio Ambiente e dos Recursos Naturais (IBAMA), contando com as novas ferramentas de monitoramento, como o sistema DETER (Projeto de Deteç̧ão do Desmatamento em Tempo Quase Real) do Instituto Nacional de Pesquisas Espaciais (INPE), e com o apoio da Polícia Federal (PF), do Exército Brasileiro (EB) e da Polícia Rodoviária Federal (PRF), alcançaram resultados significativos, ainda que não na escala esperada pelo governo federal.

Mesmo assim, houve, em 2005, no primeiro ano de execução do Plano, uma queda da taxa de desmatamento florestal. Carvalho (2012, p. 236) apresenta um panorama sucinto da Gestão Marina Silva:

\footnotetext{
A característica marcante da política de gestão ambiental Marina Silva foi fiscalização e autuação das empresas responsáveis pelo desmatamento florestal na Amazônia paraense. Neste modelo de governança preventiva, eram valorizados os fóruns e colegiados que permitiam o diálogo com a sociedade civil, as ONGs, os movimentos sociais, os segmentos empresariais e os órgãos da esfera municipal e estadual, especialmente as secretarias de meio ambiente. Na gestão da Ministra Marina Silva, o Ministério do Meio Ambiente (MMA) lançou mão de instrumentos de política ambiental para descentralizar o poder da esfera do governo federal para governos subnacionais, atores e instituições mais próximos dos problemas destruição do meio ambiente.
}

Barros-Platiau (2011) verificam que a realidade socioeconômica brasileira deste período, e a as condições materiais para viabilizar a política ambiental dos 
municípios da Amazônia paraense tornou a concretização da gestão compartilhada bastante difícil. Em 2006, a ministra Marina Silva pediu demissão do cargo de ministra do Ministério do Meio Ambiente. Imediatamente depois do ocorrido, o (ex) Presidente da Républica, Luiz Inácio Lula da Silva, convidou o Economista Carlos Minc Baumfed para assumir o Ministério do Meio Ambiente, que adotou novos mecanismos de governança centrado no combate e controle do desmatamento florestal da Amazônia.

Uma das ferramentas mais eficazes que estão sendo utilizadas no controle e combate do desmatamento florestal na Amazônia diz respeito ao licenciamento ambiental que vem sendo usado pelo IBAMA para inibir o desmatamento. Carvalho (2012, p. 241) define essa questão da seguinte maneira:

\begin{abstract}
O licenciamento ambiental como uma obrigação legal prévia para a instalação de qualquer empreendimento ou atividade potencialmente poluidora ou degradadora do meio ambiente e possui como principal característica o envolvimento dos membros da sociedade nas tomadas de decisões por meio da realização das audiências públicas e o acompanhamento do Ministério Públicos e participação das secretarias de meio ambiente dos estados da Amazônia Legal. As principais diretrizes para a execução do licenciamento ambiental estão expressas na Lei n⿳o 6.938/81 e nas Resoluções de no 001/86 e no 237/97 do Conselho Nacional do MeioAmbiente (CONAMA). Além dessas, o Ministério do Meio Amabiente emitiu recentemente parecer o 312 que discorre sobre a competência estadual e federal para licenciamento ambiental tendo como fundamento a abragência do impacto sobre a floresta.
\end{abstract}

Em 2008, a então governadora do Estado do Pará, Ana Júlia de Vasconcelos Carepa, aprovou o Decreto Estadual no 1.148, de 17/07/2008, que dispõe sobre o Cadastro Ambiental Rural no Pará - o CAR-PA - que torna obrigatório o registro cadastral de todo imóvel rural localizado no Pará, inclusive aqueles que não exercem qualquer atividade rural economicamente produtiva. O Art. $2^{o}$ do referido decreto estadual é claro quando diz que "não será concedido licenciamento de qualquer natureza para o imóvel que não esteja cadastrado no CAR-PA".

O resultado dessa ação foi o aumento do número de propriedades rurais cadastradas que é o primeiro passo para a regularização ambiental das terras. Em 2007, só 10 propriedades rurais estavam registradas no CAR-PA. Em 2010, esse número subiu para 52.000. Verifica-se, portanto, que a combinação de ações eficientes de fiscalização, das autuações de multas pagas e o esforços para regularizar as terras do setor produtivo e pode ser um dos caminhos para a redução dos crimes ambientais como o desmatamento da floresta amazônica paraense.

De acordo com o Procurador da República no Pará, Daniel César Azeredo Avelino, um dos efeitos positivos da campanha foi o fato do Estado conseguir inscrever 45 mil propriedades no Cadastro Ambiental Rural (CAR), promovendo a identificação e a regularização ambiental das propriedades e posses rurais e sua 
inserção na base de dados da Secretaria de Estado de Meio Ambiente (SEMA) de maneira ágil e eficiente.

Outro ponto positivo refere-se a uma queda progressiva no tamanho das áreas desmatadas. "Desde 2009, o desmatamento vem registrando uma queda histórica," ressalta o Procurador da República no Estado do Pará em entrevista concedida ao Jornal O Liberal de 2012. Na concepção Carvalho (2012, p. 241):

Outra alternativa à redução dos crimes ambientais é a vigilância do mercado consumidor. Foi o que aconteceu com a cadeia produtiva da pecuária no Pará, em 2009. Depois da atividade pecuária ser apontada como sendo a principal atividade responsável pelo desmatamento no Pará, supermercados, frigoríficos pecuaristas firmaram um Termo de Ajuste de Conduta (TAC). Além disso, os frigoríficos passaram a comprar gado bovino de pecuaristas com a situação fundiária regularizada, inscritos no CAR-PA.

Esse novo mecanismo de governança, no âmbito estadual, contribuiu para a redução do desmatamento florestal, o que de fato pode ser visto na Tabela 1 no perído de 2003 a 2010. No Estado do Mato Grosso, por exemplo, o controle pelo cumprimento da legislação começa a partir da exigência de que os proprietários rurais têm que aderir ao programa de regularização ambiental chamado Mato Grosso Legal, e comprovem a inscrição no Cadastro Ambiental Rural (CAR) para manterem os laços comerciais com os frigoríficos.

De acordo com o Ministério Público do Pará, no ano de 2012, a mudança começou praticamente do zero, pois a primeira exigência foi à inscrição dos fazendeiros no Cadastro Ambiental Rural (CAR) da Secretaria de Meio Ambiente (SEMA). “O CAR é o primeiro passo para a obtenção de qualquer licença ambiental para uso ou exploração dos recursos naturais da propriedade rural e para realizá-lo, os pecuaristas são obrigados a apresentar um mapa georreferenciado da propriedade rural, ou seja, o levantamento do perímetro da área", pontua Carvalho (2012, p. 243).

Tabela 1: Desmatamento Florestal por Estados da Amazônia Legal em Km²/ano: 2003-2010

\begin{tabular}{|c|c|c|c|c|c|c|c|c|}
\hline Estados $\backslash$ Ano & 2003 & 2004 & 2005 & 2006 & 2007 & 2008 & 2009 & 2010 \\
\hline Acre & 1078 & 728 & 592 & 398 & 184 & 254 & 167 & 259 \\
\hline Amazonas & 1558 & 1232 & 775 & 788 & 610 & 604 & 405 & 595 \\
\hline Amapá & 25 & 46 & 33 & 30 & 39 & 100 & 70 & 53 \\
\hline Maranhão & 993 & 755 & 922 & 674 & 631 & 1271 & 828 & 712 \\
\hline Mato Grosso & 10405 & 11814 & 7145 & 4333 & 2678 & 3258 & 1049 & 871 \\
\hline Pará & 7145 & 8870 & 5899 & 5659 & 5526 & 5607 & 4281 & 3770 \\
\hline Rondônia & 3597 & 3858 & 3244 & 2049 & 1611 & 1136 & 482 & 435 \\
\hline Roraima & 439 & 311 & 133 & 231 & 309 & 574 & 121 & 256 \\
\hline Tocantins & 156 & 158 & 271 & 124 & 63 & 107 & 61 & 49 \\
\hline Amazônia Legal & 25396 & 27772 & 19014 & 14286 & 11651 & 12911 & 7464 & 7000 \\
\hline
\end{tabular}

Fonte: INPE (2011). 


\subsection{A rastreabilidade como mecanismo de governança eficaz no combate do Desmatamento}

Em 2012, outro fator que que colaborou para a queda do desmatamento florestal na Amazônia paraense diz respeito a implementação do sistema de rastreamento da cadeia bovina (track number). Primeiramente, é preciso entender que o controle sobre a produção pecuária é feito hoje apenas por meio da Guia de Transporte Animal (GTA) exigida pelos governos estaduais com o principal objetivo de evitar a propagação de doenças no rebanho.

A GTA contém o registro de quem vendeu e de quem comprou, e por onde o gado foi transportado. Um dos compromissos assumidos pelo governo do Pará na assinatura do TAC foi o de implantar o mesmo sistema, o que facilita o trabalho dos órgãos de fiscalização, ressalta o Ministério Público do Pará. No entanto, a GTA não identifica cada boi. Atualmente, este controle individual dos animais só é feito pelo Serviço Brasileiro de Rastreabilidade da Cadeia Produtiva de Bovinos e Bubalinos (SISBOV), um sistema de rastreamento mais detalhado, subordinado ao Ministério da Agricultura, que por enquanto só é obrigatório para quem exporta para a União Europeia.

Sobre isso, Carvalho (2012, p. 243) observa:

Os proprietários de fazendas com até quatro módulos fiscais que não
tenham condições técnicas e financeiras para fazer o cadastro podem pedir
ajuda diretamente a SEMA ou a Empresa de Assistência Técnica e Extensão
Rural (EMABTER). Dessa forma, as informações cadastradas serão cruzadas
com imagens obtidas via satélite pelo INPE para se averiguar a existência de
desmatamento além do permitido.

Essa tecnologia já estava disponível, no entanto, como eram muito poucos os fazendeiros paraenses cadastrados, não se faziam as imagens por satélite das propriedades, e só agora elas estão sendo feitas. Embora a inscrição no CAR já fosse uma obrigação legal, muitos fazendeiros a ignoravam - seja por resistência cultural de longa data ou pelo receio em relação ao custo de implementação deste tipo de procedimento. Até junho de 2009, antes do acordo com o Ministério Público Federal do Pará, havia cerca de 400 produtores inscritos no CAR no Pará. Em 2012, foram identificadores mais de 21 mil produtores inscritos.

Além disso, a GTA eletrônica ajuda a evidenciar qualquer tipo de fraude, e impede que alguém que não tenha feito o registro possa transportar o gado com a guia de outra pessoa, pois como forma de manter o controle, cada fazendeiro tornase responsável por uma conta bancária, na qual consta a localização da fazenda e a contabilidade do gado que vendeu, comprou e que ainda possui. Nesse contexto, Carvalho (2012, p. 244) conclui:

As fiscalizações que estão sendo feitas atualmente através de auditorias, estabelecendo um cruzamento dos dados das áreas cadastradas com as imagens de satélite serão de suma importância, já que esse tipo de auditoria tem a capacidade de evitar fraudes, como, por exemplo, um fazendeiro 
emitir a GTA em seu nome para transportar gado de um vizinho que não está inscrito no CAR. O empréstimo do registro pode ser detectado pela auditoria se a quantidade de gado transportada pela fazenda não for compatível com o rebanho declarado pelo produtor à Agência de Defesa Agropecuária do Pará (ADEPARÁ) como sendo de sua propriedade.

Desta maneira, o Ministério Público do Pará, destaca a importância do auxílio institucional da rastreabilidade, já que quando é conhecida a origem de um produto, torna-se mais acessível saber se ele foi feito de acordo com a legislação, isto é, se ele é um processo que nos permite "seguir o rastro" de um produto até conseguirmos chegar à origem dele. Além disso, se na embalagem da carne forem apresentadas informações relativas à localização da carne, também será mais fácil saber se as leis socioambientais foram obedecidas, onde consumidor poderá optar por comprar apenas os produtos provenientes de fazendas que respeitem a legislação e o meio ambiente.

Carvalho (2012) chama a atenção para o fato do Banco Nacional de Desenvolvimento (BNDES) ter ampliado as exigências para o setor de pecuária, já que a referida instituição financeira passou a cobrar dos frigoríficos financiados a adesão do sistema de rastreabilidade da cadebia bovina, e a exigir a verificação de regularidade socioambiental. "Outro exemplo importante a ser seguido foi demonstrado pelas empresas norte-americanas, Nike e Timberland, que afirmaram que não usarão mais em seus produtos qualquer tipo de material de couro vindo da Amazônia sem garantia de origem legal", destaca Carvalho (2012, p. 245).

Em 2012, de acordo com o Ministério Público do Pará, isso gerou um impacto muito forte em empresas multinacionais, já que o grupo brasileiro MARFRIG Alimentos - quarto maior produtor de carne bovina e derivados do mundo antecipou-se e, mesmo sem ter recebido qualquer tipo recomendação, comprometeuse a não comprar mais gado de fazendas que desmatam na Amazônia.

Cabe ressaltar que a rastreabilidade da cadeia bovina teve suporte institucional do próprio Governo Federal, já que o (ex) Presidente da República, Luiz Inácio Lula da Silva, publicou a Lei n⿳0 12.097, de 24 de novembro de 2009, que tem como objetivo evitar o embargo da carne e outros produtos oriundos da pecuária brasileira no exterior. A lei disciplina a chamada rastreabilidade na cadeia produtiva da carne bovina, um sistema de registro e acompanhamento das informações referentes às diversas fases dessa atividade, bem como ajuda na fiscalização e combate ao desmatamento florestal na Amazônia.

\section{CONSIDERAÇÕES FINAIS}

Além das causas estruturais e institucionais, responsáveis pelo avanço da fronteira pecuária na Amazônia paraense, decorrente do seu atraso histórico como periferia em relação ao centro do capitalismo brasileiro, há também aqueles fatores conjunturais (migração, preço da terra, crédito, aberturas de estradas, incentivos fiscal-financeiro, proximidades de cidades e valorização da carne bovina) que 
acentuam a taxa do desmatamento florestal. Para Carvalho (2012), Na fronteira agropecuária amazônica, o governo militar, para manter a ordem social, criou instituições e organizações de controle dos fluxos das populações migrantes de outras regiões.

Nesse contexto, a política do governo da ditadura militar de transformar a Amazônia numa fronteira agropecuária só ganhou efetividade com a criação das instituições que deram respaldo legal a ação do Estado. Em boa medida as demais organizações (INCRA, IBDF e FUNAI) passaram a secundar as ações dos agentes principais: a SUDAM e o BASA. Mas, como o modelo de desenvolvimento capitalista do Brasil resultou no aumento da dívida externa, o governo federal foi forçado a intensificar a atuação da SUDAM e do BASA em prol das atividades agropecuárias, madeireiras e de mineração.

O próprio Carvalho (2012) reforça essa ideia quando sustenta que o fato do governo federal, através dessas duas organizações regionais, dirigir e concentrar seus gastos em infraestrutura econômica de suporte ao grande capital revela sua postura frente ao grande capital nacional e transnacional como principal agente para desenvolver as forças produtivas sociais no processo de ocupação da fronteira agropecuária na Amazônia Legal. Contudo, os efeitos dessa estratégia, proporcionada pelas organizações do Estado, acabaram criando várias zonas de conflitos sociais na luta pela terra entre as frentes de expansão camponesas, e as frentes pioneiras de expansão da agropecuária capitalista.

É claro que essa expansão da fronteira agropecuária na Amazônia coloca e recoloca o problema da posse e uso da terra ao lado do problema do desmatamento florestal. Isto é assim porque a expansão da agropecuária na Amazônia Legal, sobretudo na Amazônia paraense, se deu e vem se dando com o aproveitamento extensivo das pastagens artificiais. Em síntese, os principais fatores responsáveis pela expansão da fronteira agropecuária e a dinâmica do desmatamento florestal na região são: rebanho bovino, crescimento econômico (PIB), crédito rural concedido à pecuária, preço da terra e gastos com gestão ambiental.

O rebanho bovino é um ativo que têm a propriedade de ser reserva de valor, isto é, possui liquidez suficiente para ser convertido em dinheiro a qualquer momento com menor custo possível, e ao mesmo tempo, quando transformado em carne industrializada, um bem de consumo alimentar de grande procura no mercado nacional e internacional, o que colabora para que tanto o preço da terra nua quanto o tamanho do rebanho bovino favoreçam a expansão da fronteira pecuária rumo às áreas de florestas densas, causando o desmatamento.

Do ponto de vista institucional, o rebanho bovino é uma mercadoria com poder para garantir a posse da terra, fato este de suma importância numa região de fronteira como a do Pará. A pecuária de corte em regime extensivo exige baixos custos iniciais, principalmente, quando subsidiada por alguma instituição, com uma capacidade de retorno financeiro muito mais compensadora, sendo que mesmo em 
um território extenso como o paraense a questão da logística envolvendo manuseio e transporte do gado não é um problema aparente para o pecuarista.

Prates e Serra (2009), por exemplo, demonstram que melhorando o sistema de transporte, por meio de sua ampliação ou remodelação, os custos de transporte diminuem, o que estimula ou viabiliza a implantação de atividades que necessitem do solo e que concorram com a floresta. Além disso, os referidos autores colocam que diversos trabalhos apontam para as redes de estradas não oficiais ou clandestinas como grande causadora do desmatamento florestal. No entanto, os próprios autores ponderam que as estradas não oficiais estão conectadas às oficiais; assim, a expansão das oficiais permite ao longo do seu eixo a ramificação das não oficiais.

As atividades econômicas que caracterizam o atual processo de ocupação e desmatamento - sobretudo o extrativismo madeireiro não sustentável e a pecuária de grande escala - não fazem um uso socialmente ótimo da rica base de recursos naturais. Margulis (2003) tem destacado a pecuária de corte em regime extensivo como a principal atividade econômica da região, em decorrência da viabilidade financeira dos grandes e médios pecuaristas, tornando-se fonte importante do processo de desmatamento florestal da Amazônia brasileira respondendo, atualmente, por aproximadamente $75 \%$ das áreas desmatadas na região.

Outro aspecto importante diz respeito à relação entre o crescimento econômico e o desmatamento florestal, que é evidente nos indicadores socioeconômicos da Amazônia brasileira. Não obstante a elevação de indicadores socioeconômicos, como a renda per capita, por exemplo, observam-se grandes desigualdades na região, sobretudo no que tange a distribuição da renda e a qualidade de vida da população local.

Logo, é legítimo argumentar que os significativos ganhos privados das atividades econômicas desenvolvidas na região Amazônica são largamente excludentes, pouco tendo contribuído para aliviar as persistentes desigualdades sociais e econômicas nitidamente observadas ao nível local na região. Nestes termos, identificar as dinâmicas da trajetória de crescimento intra-regional na Amazônia pode servir como um poderoso instrumento para auxiliar a formulação de políticas mais eficientes de desenvolvimento regional.

Nas palavras de Prates e Serra (2009, p. 111-112), “o crédito rural tem a capacidade de fornecer recursos financeiros para os produtores expandirem suas atividades". Da mesma forma, os gastos do governo em agricultura criam condições, tanto materiais quanto institucionais, para a expansão da atividade agropecuária. Isso revela que, conforme o governo disponibiliza recursos para financiar a atividade da agropecuária, ela se expande para novas áreas elevando o desmatamento.

É importante ressaltar que o crédito rural é, em última instância, uma decisão governamental e que pode estar dentro de uma política de desenvolvimento regional. Desta forma, indiretamente, o governo financia o desmatamento florestal na região por meio do crédito rural. De acordo com os estudos realizados pelo Banco 
Central no ano de 2011, entre os anos de 2000 e 2009, foram concedidos $\mathrm{R} \$ 52,353$ bilhões em crédito rural para estados da Amazônia Legal.

Desse montante financeiro, 13,222 bilhões foram custeados com recursos dos Fundos Constitucionais de Financiamento das Regiões Norte (FNO), Nordeste (FNE) e Centro-Oeste (FCO), previstos no art. 159, I, c, da própria Constituição Federal, onde no Estado do Pará foi investido no período de 1999 a 2006 um valor em torno de $\mathrm{R} \$ 3,16$ bilhões em crédito rural, sendo que desse total, $\mathrm{R} \$ 1$ bilhão foi destinado para agricultura ( $\mathrm{R} \$ 1$ bilhão), e $\mathrm{R} \$ 2,15$ bilhões para pecuária. Com base nesses dados, é possível pensar que o volume de crédito rural pode vir a se relacionar de forma direta com o desmatamento florestal.

No Estado do Pará, a corrida por ocupação de terras na fronteira tem aumentado às disputas pela posse da terra. $\mathrm{O}$ resultado disso têm sido o aumento do preço da terra e o interesse dos grandes pecuaristas por extensas áreas de terras na fronteira amazônica para o desmatamento com vistas à formação de pastos.

A tendência da alta do preço da terra pode inibir ainda mais a absorção dos posseiros e sem-terras através de suas próprias economias domésticas, o que significa que somente pela via da reforma agrária é possível acomodar o grande contingente da mão-de-obra rural com potencial produtivo na fronteira amazônica, argumentam Almeida e David (1980).

A definição econômica do quanto depende a exploração agropecuária do preço da terra na Amazônia, somente pode ser percebida quando se confronta o valor imobilizado na compra da terra com os demais investimentos produtivos na propriedade. Sabe-se que o preço da terra, enquanto um ativo real que tem uma relativa liquidez por ser reserva de valor, varia de região para região, de acordo com as variáveis da região onde se localiza a terra agricultável: grau de densidade demográfica, estágio de desenvolvimento econômico, logística de transportes em relação aos centros consumidores, além das qualidades físicas de solo e clima.

Além disso, enquanto a questão do direito de propriedade das terras dos posseiros não for resolvida e a reforma agrária não acomodar as famílias de trabalhadores rurais conhecidos por sem-terra, os conflitos agrários na fronteira amazônica irão perdurar por mais tempo. Os conflitos geradores de mortes são o resultado do antagonismo entre a propriedade privada familiar e a propriedade privada capitalista.

Segundo Carvalho (2012), nos últimos vinte e cinco anos, a expansão da fronteira agropecuária tem sido acompanhada de mudanças nas condições do produtor rural no Estado do Pará com destaque às categorias dos ocupantes e proprietários. Atualmente, entretanto, há uma necessidade de uma reconceituação regional da propriedade da terra, pois não pode ser mantido o formalismo jurídico das instituições - direito civil, legislação dos registros públicos, as certidões cartoriais, as mediações formais e superficiais das organizações federais e outras práticas jurídicas ou administrativas - que não conseguem resolver a questão agrária e do desmatamento florestal na região amazônica. 
Outro aspecto conclusivo importante diz respeito aos gastos do Governo com gestão ambiental, que consistem em realizações do governo federal, estadual e até municipal, cujo objetivo é preservar o estado natural de determinada área pertencente ao município ou sua recuperação quando algum dano ambiental estiver incidido sobre essa área, porém, esses gastos são os menos expressivos em termos financeiros.

A expressão governança ou gestão são termos contemporâneos, utilizados como sinônimo de administração ou gerência, que englobam as ações pertinentes à obtenção e utilização dos recursos necessários e ao estabelecimento de relações demandadas e dirigidas para um propósito comum de uma dada organização privada ou pública. A governança ambiental tem o propósito organizar as atividades humanas por intermédio das instituições definidoras das "regras do jogo", no sentido de North (1990), visando reduzir os impactos da ação humana sobre o meio ambiente.

Neste contexto, as novas instituições criadas para combater o desmatamento florestal no período da Nova República, bem como os mecanismos de governança adotados nas políticas federais e estaduais de gestão ambiental, principalmente, com os investimentos direcionados para a fiscalização, qualificação de mão de obra, custeio com equipamento, licenciamento ambiental e a rastreabilidade da cadeia bovina, tem atuado de maneira muito eficaz e positiva para a redução do desmatamento florestal na região, ou seja, quanto maiores forem os gastos com gestão ambiental, maior será a redução da taxa de desmatamento florestal na Amazônia paraense.

Daudelim (2008) ressalta a importância dos mecanismos de governança formais e alternativos de encaminhamento da resolução das disputas, e conflitos pela posse da terra, o que segundo ele requer o preenchimento de pré-requisitos institucionais adequados à solução do problema, dos quais podemos citar: a eficácia imediata espacial e temporal para a resolução por meios não violentos dos conflitos da luta pela terra; os custos que irão influenciar os atores envolvidos na preferência da escolha de um dentre os vários mecanismos de governança disponíveis à resolução das disputas e conflitos de forma judicial ou administrativa pela instância competente; e a validade dos acertos no longo prazo do resultado do processo de resolução das disputas e conflitos da luta pela terra.

É possível que no futuro as propriedades institucionais possam até a vir substituir as formas tradicionais de propriedade privada capitalista e camponesa, mas no momento atual no Brasil a reforma agrária é a forma mais indicada para resolver o problema da luta pela terra. Nestas condições, não se pode descartar a discussão que vem sendo realizada no Brasil sobre métodos institucionais alternativos de resolução de disputas - baseados em regras consuetudinários, arbitragem, conciliação ou na mediação por terceiros - vêm sendo defendidos como soluções alternativas quando o regime formal da propriedade da terra e os meios de 
resolução dos conflitos se mostram incapazes de encontrar soluções eficazes e imediatas, válidas e de custo baixo para as disputas de terra.

Percebe-se, portanto, que fronteira não necessariamente é uma região distante ou um território vazio em termos de densidade demográfica. "Ela é fronteira do ponto de vista do capital, isto é, como uma relação social de produção capitalista", conforme relata Graziano Da Silva (1981, p. 114-116). Assim sendo, a fronteira econômica é uma relação social de produção porque a estrutura da sociedade em construção no território da fronteira é dominada (in) diretamente pelo capital.

\section{REFERÊNCIAS}

ALMEIDA, A. L. O; DAVID, M. B de A. Tipos de Fronteiras e Modelos de Colonização na Amazônia: Revisão da literatura e especificação de uma pesquisa de campo. Brasília, INPES/IPEA, 1980.

ALSTON, L. J.; LIBECAP, G.; MUELLER, B. Titles, Conflict, and Land Use: The Development of Property Rights and Land Reform on the Brazilian Amazon Frontier, University of Michigan Press, 1999.

ALSTON, L. J.; MUELlER, B.. Property Rights, Violence and the State. Departamento de Economia: Série Textos para Discussão. Universidade de Brasília, 2003.

ANUATTI NETO, F.. Regulamentação dos Mercados. In: PINHO, Diva Benevides; VASCONCELLOS, Marco Antônio S. De. (Org.). Manual de Economia. São Paulo, 5.ed. Saraiva, 2004.

BARROS-PLATIAU, A. F. O Brasil na Governança nas Grandes Questões Ambientais Contemporâneas. Texto para Discussão, 1618. Brasília, IPEA, 2011.

BECKER, B.K. Síntese do processo de ocupação da Amazônia: lições do passado e desafio do presente. In: Brasil: causas e dinâmicas do desmatamento na Amazônia. Brasília, MMA, 2000.

CAMPOS, R. A Lanterna na Popa: Memórias. Rio de Janeiro, Topbooks, 1994.

DEMSETZ, H. Toward a theory of property rights. American Economic Review, Nashville, no 57, p. 347-359, May 1967.

CARVALHO, D. F. Estado, Governabilidade e Governança. Anais do 59a Congresso Anual da SPPC. Belém, SPBC, 2007. 
CARVALHO, A. C. Expansão da Fronteira Agropecuária e a Dinâmica do Desmatamento Florestal na Amazônia Paraense. Campinas, SP. Tese de Doutorado - Universidade Estadual de Campinas, Instituto de Economia, 2012.

CARVALHO, A. C.; CARVALHO, D. F.; VERAS, F. F. S. Fundamentos Teóricos para a Compreensão da Nova Economia Institucional. In: Anais do XXI Encontro Regional dos Estudantes de Economia - XXI ERECO, São Luiz-MA, 2014.

COASE, R.H. The problem of social cost. Journal of Law and Economics, vol. 3, Oct., p. 1-44, 1960.

COASE, R.H. The Firm, the Market, and the Law. Chicago, University of Chicago Press, 1988.

DAUDELIN, J. Resolução Alternativa de Disputas em Conflitos de Terra. In: Luta pela Terra, Reforma Agrária e Gestão de Conflitos no Brasil. Antônio Márcio Buainain (Coord.). Campinas, SP, UNICAMP, 2008.

DEMSETZ, H. Toward a theory of property rights. American Economic Review, Nashville, no 57, p. 347-359, May 1967.

FISHER, S., DORNBUSCH, R. Introduction to Macroeconomics, USA, McGraw-Hill Companies, 1983.

FOWERAKER, J. A Luta pela Terra: a economia política da fronteira pioneira no Brasil de 1930 aos dias atuais. Rio de Janeiro, Zahar, 1982.

FURTADO, C. Formação Econômica do Brasil. São Paulo, Ed. Nacional, 1976.

GRAZIANO DA SILVA, J. A porteira já está fechando. A Modernização Dolorosa: Estrutura agrária, fronteira agrícola e trabalhadores rurais no Brasil. RJ: Zahar, 1981.

HÉBETTE, J; MARIN, R. E. A. Colonização e Fronteira: articulação no nível econômico e no nível ideológico. Cruzando Fronteira: 30 anos de estudo do campesinato na Amazônia, Vol. I. Belém, Universidade Federal do Pará, 2004.

HOFSTADER, R.; LIPSET, S. M. Turner and the Sociology of the Frontier. New York, Basic Books Inc, 1968.

INSTITUTO NACIONAL DE PESQUISAS ESPACIAIS - INPE. Relatório Monitoramento da Cobertura florestal da Amazônia por Satélites. Sistemas 
PRODES, DETER, DEGRAD E QUEIMADAS 2007-2008. INPE, Ministério da Ciência e Tecnologia, 2011.

LENIN, V. I. Capitalismo e Agricultura nos Estados Unidos da América. Novos dados sobre as leis de desenvolvimento do capitalismo na agricultura. SP: Brasil Debates, 1980.

MARGULIS, S. Causas do desmatamento da Amazônia brasileira. Technical report, Banco Mundial, 2003.

MARTINS, J. de S. Fronteira: A degradação do Outro nos Confins do Humano. SP: Contexto, 2009.

MARX, K. O Capital: Crítica da Economia Política. Rio de Janeiro, Civilização Brasileira. Livro 1, Vol.2, 1982.

MI/SUDAM. Operação Amazônia. Belém, Serviço de Documentação e Divulgação, 1968.

MORSE, R. M. (ed.) The Bandeirantes - the historical role of the brazilian pathfinders. New York: Alfred Knopf-Borzoi Books, 1965.

NELSON, R.; WINTER, S. Uma teoria Evolucionista da Mudança Econômica. Campinas-SP, UNICAMP, 2005.

NORTH, D. C. (1990). Institutions, Institutional Change and Economic Performance. New York, Cambridge University Press.

OSTROM, E.; HESS, C. A framework for analyzing the knowledge commons. In: Understanding Knowledge as a Commons. Edited by Charlotte Hess and Elinor Ostrom, The Mit Press, Cambridge, Massachusetts, London, England, 2007.

POLANYI, K. The Great Transformation. New York: Beacon, 1957.

PRATES, R. C.; SERRA, M. A. O impacto dos gastos do governo federal no desmatamento no Estado do Pará. Nova Economia, vol.19, n.1, pp. 95-116, 2009.

PRZEWORSKI, A. Sobre o desenho do Estado: uma perspectiva agent x principal. In: Reforma do Estado e Administração Pública Gerencial. Orgs. PEREIRA, Carlos Bresser Luiz e SPINK, Peter Kevin. Rio de Janeiro: Fundação Getúlio Vargas, 1998.

SANDRONI, P. Dicionário de economia do século XXI. Rio de Janeiro: Record, 1999. 
TURNER, F. J. The Significance of the Section in American History. In: Frontier and Section: Selected Essays of Frederick J. Turner. New Jersey, Prentice-Hall, p.217-233, 1961.

VATN, A. Institutions and the Environment. Edward Elgar. Cheltenham, UK, 2005.

VELHO, O. G. Frentes de Expansão e Estrutura Agrária: Um estudo do processo de penetração numa área da Transamazônica. Rio de Janeiro, Zahar, 1972.

VELHO, O. G. Capitalismo Autoritário e Campesinato: um estudo comparativo a partir da fronteira em movimento. São Paulo, Difel, 1976.

WILLIAMSON, O. E. The Economic Institutions of Capitalism: Firms, Markets, Relational Contracting. New York, The Free Press, 1985.

WILLIAMSON, O. E. The Mechanisms of Governance. Oxford University Press, 1996. 